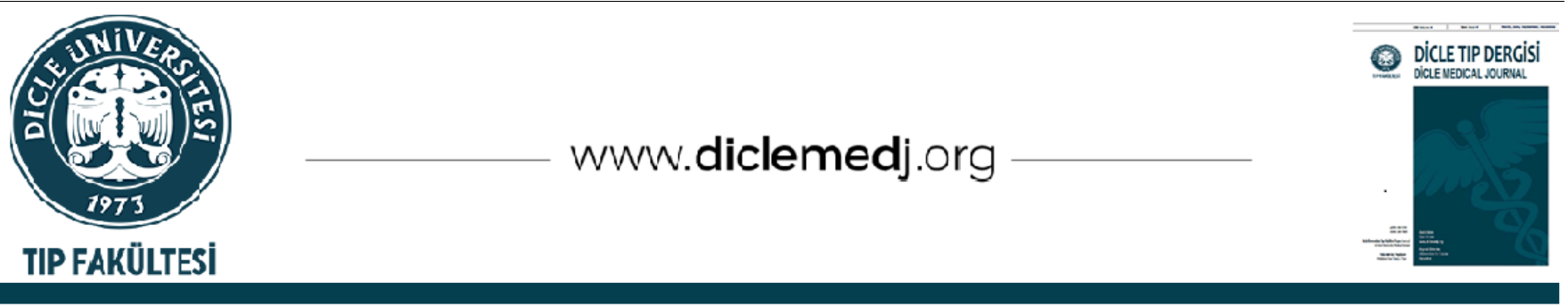

\title{
Valproik Asit Uygulamasının Embriyo İmplantasyon Bölgesinde Vazoaktif İntestinal Peptid ve Siklooksijenaz-2 Aktivitesi Üzerine Etkisi
}

\author{
Gülce Naz Yazıcı ${ }^{D} 1$, Seren Gülșen Gürgen ${ }^{D}{ }_{2}$, Mukadder Sunar ${ }^{i}{ }_{3}$, Ali Cansu ${ }^{2} 4$ \\ 1 Erzincan Binali Yıldırım Üniversitesi Tıp Fakültesi, Histoloji ve Embriyoloji Anabilim Dalı, Erzincan, Türkiye \\ 2 Celal Bayar Üniversitesi Mesleki Sağlık Hizmetleri Yüksekokulu, Histoloji ve Embriyoloji Anabilim Dalı, Manisa, Türkiye \\ 3 Erzincan Binali Yıldırım Üniversitesi Tıp Fakültesi, Anatomi Anabilim Dall, Erzincan, Türkiye \\ 4 Karadeniz Teknik Üniversitesi Tıp Fakültesi, Çocuk Nörolojisi Anabilim Dalı, Trabzon, Türkiye \\ Geliş: 30.07.2021; Revizyon: 23.11.2021; Kabul Tarihi: 27.11.2021
}

Öz

Amaç: Epilepsi, günümüzde milyonlarca kişiyi etkileyen elektrokimyasal bir beyin fonksiyonu bozukluğudur. Epilepsi hastalı̆̆ı, yapılan çalışmalarla kadın ve erkeklerde yüksek üreme bozukluğu prevalansı ile ilişkilendirilmiştir. Uzun süre tedavi gerektiren bu hastalık için sıklıkla reçete edilen bir antiepileptik ilaç olan valproik asitin, ovaryumda ergenlik öncesinden yetişkinliğe kadar apoptotik etkilere ve folikülogenez bozukluğuna neden olarak üremeyi olumsuz etkilediği bilinmektedir. Çalışmamızın amacı valproik asit (VPA) uygulanan siçanlarda embriyo implantasyonunda siklooksijenaz-2 (COX-2) ve vasoaktif intestinal peptid (VIP) moleküllerinin implantasyon döneminde dağılımının araştırılmasıdır.

Yöntemler: 20 adet diși sıçan iki gruba randomize olarak bölünerek, 1. Grup Kontrol, 2. Grup VPA Grubu olarak belirlendi. 1. Gruba; 90 gün boyunca salin solusyonu intraperitoneal olarak iki doz şeklinde uygulandı. 2. Gruba ise 90 gün boyunca 300 mg/kg/gün VPA intraperitoneal olarak iki doz şeklinde uygulandı. Denekler kontrollü olarak erkek sıçanlarla çiftleştirildi; çiftleşme günü 0 . Gün kabul edildi ve 7. Günde denekler yüksek doz anestezi altında feda edilerek uterus implantasyon bölgesi dokuları çıkartıldı. Dokulara, immünohistokimyasal değerlendirme yapılarak bulgular istatistiksel verilerle karşılaştırıldı.

Bulgular: Çalışmamızda, COX-2 primer antikoru ile yapılan immünohistokimyasal işaretlemede 7. Gün kontrol grubuna ait kesitlerde, desidua, embriyonun trofoektodermi ve uterus bez epitelinde, kuvvetli bir immünreaksiyon izlenirken; 7. Gün VPA grubuna ait kesitlerde COX-2 antikoru ile yapılan işaretlemesinde ise, immünreaksiyonun aynı bölgelerde zayıf tutulumda olduğu izlendi. VIP primer antikoru ile yapılan immünohistokimyasal işaretlemede 7. Gün kontrol grubuna ait kesitlerde, desiduada zayıftan ortaya değişen kuvvette immünreaksiyon gözlemlenirken, embriyonun trofoektoderminde orta kuvvette, uterus bez epitelinde ise zayıf orta kuvvette immünreaksiyon ayırt edildi. 7. Gün VPA grubuna ait kesitlerin VIP antikoru ile yapılan işaretlemesinde ise, desiduada, embriyonun trofoektodermi ve uterus bez epitelinde negatiften zayıfa değișen immünreaksiyon gözlemlendi.

Sonuç: Çalışmamızda yaptığımız immünohistokimyasal değerlendirme ve destekleyici istatistiksel veriler ışığında; VPA 'nın uzun süre kullanımının gebelik sürecinde COX-2 ve VIP 'nin ifadelenmesini azalttığı; bu azalmanın da embriyo implantasyonunu ve dolayısıyla gebeliğin ilerlemesini olumsuz yönde etkileyerek risk oluşturabileceği kanısına varılmıştır.

Anahtar kelimeler: Epilepsi, İmplantasyon, VPA

DOI: 10.5798/dicletip.1037848

Yazışma Adresi / Correspondence: Gülce Naz Yazıcı, Erzincan Binali Yıldırım Üniversitesi Tıp Fakültesi, Histoloji ve Embriyoloji Anabilim Dalı, Erzincan, Türkiye e-mail: gulcenazyazici.ank@gmail.com 


\title{
The Effect of Valproic Acid Application on Vasoactive Intestinal Peptide and Cyclooxygenase- 2 Activity in the Embryo Implantation Region
}

\begin{abstract}
Objective: Epilepsy is an electrochemical brain dysfunction that affects millions of people today. Epilepsy disease has been associated with a high prevalence of reproductive disorders in men and women in the light of studies. It is known that valproic acid, an antiepileptic drug that is frequently prescribed for this disease that requires long-term treatment, adversely affects reproduction by causing apoptotic effects and folliculogenesis disorder in the ovary from pre-adolescence to adulthood. The aim of our study was to investigate the distribution of cyclooxygenase-2 (COX-2) and vasoactive intestinal peptide (VIP) molecules during embryo implantation in rats administered valproic acid (VPA).

Method: 20 female rats were randomly divided into two groups, Group 1 was determined as Control, Group 2 as VPA Group. 1. Group; Saline solution was administered intraperitoneally in two doses for 90 days. In Group 2, $300 \mathrm{mg} / \mathrm{kg} / \mathrm{day}$ VPA was administered intraperitoneally in two doses for 90 days. Subjects were mated with male rats in a controlled cages and manner; mating day was accepted as day 0 and on day 7, the subjects were sacrificed under high-dose anesthesia and the tissues of the uterine implantation site were removed. Tissues were evaluated by immunohistochemistry and the findings were compared with statistical data.

Results: In the immunohistochemical staining with COX-2 primary antibody, a strong immunoreaction was observed in the decidua, trophectoderm of the embryo and uterine gland epithelium in the sections belonging to the 7 th day control group; On the sections in the 7 th day of VPA group, the immunoreaction was observed to be weak in the same regions in staining with COX-2 antibody. In the another immunohistochemical staining with VIP primary antibody, immunoreaction of varying strength from weak to medium was observed in the decidua in the sections of the control group on the 7th day, moderate strength in the trophectoderm of the embryo, and weak to moderate immunoreaction in the uterine gland epithelium. On the 7th day, when the sections belonging to the VPA group were labeled with VIP antibody, an immunoreaction ranging from negative to weak was observed in the decidua, the trophectoderm of the embryo and the uterine gland epithelium.

Conclusion: With the immunohistochemical evaluation and supporting statistical data in our study; Long-term use of VPA reduces the expression of COX-2 and VIP during pregnancy; It has been concluded that this decrease may adversely affect embryo implantation and thus the progression of pregnancy and pose a risk.
\end{abstract}

Keywords: Epilepsy, Implantation, VPA.

\section{GíRiş}

Epilepsi kronik bir sendromdur, günümüzde yaklaşı 50 milyon kişiyi etkilediği düşünülmektedir ve etiyolojiye göre genellikle uzun süreli farmakolojik tedavi gerektirir. Kusursuz bir antiepileptik ilaç (AEİ) yoktur ancak son on yllda iyileştirilmiş etkinlik ve yan etki profiline sahip birçok AEİ geliştirilmiştir. Esas olarak etkinliği nedeniyle en sık önerilen AEİ 'lerden biri olan valproik asit (VPA; 2propilpentanoik asit), 1967 'den itibaren neredeyse 50 yıldır epilepsi tedavisi için kullanılmaktadır ${ }^{1}$. VPA, geniş bir antiepileptik etkinlik yelpazesine sahiptir ve bunun yanı sira bipolar bozukluklar, nöropatik ağrı ve migren profilaksisi için bir duygu durum dengeleyicisi olarak da reçete edilir. VPA 'nın epilepsi ve bipolar duygu durum bozukluğu hastalarında sık görülmekte olan üreme işlev bozukluğundaki rolü ise tartışmalıdır ${ }^{2,3}$.

Epilepsi hastalığı, kadın ve erkeklerde yüksek üreme bozukluğu prevalansı ile ilişkilidir. $\mathrm{Bu}$ bozukluklar arasında ovulasyon, menstrüel döngü bozuklukları, hiperandrojenizm, azalmış oral kontrasepsiyon etkinliği, kadınlarda olumsuz gebelik sonuçları olarak sayılabilir. Erkeklerde ise cinsel işlev bozukluğu, androjen eksikliği semptomları, testis atrofisi, bozulmuş spermatogenez gibi üreme bozukluklarına neden olmaktadır². Epilepsi kendi başına üreme bozukluklarının gelişimi ile ilişkili olabilirken", antiepileptik ilaçların bu bozuklukların gelişiminde önemli bir rol oynadığını ve epilepsinin kendisinden daha önemli olabileceğini düşündüren bir veri birikimi söz konusudur ${ }^{5}$. Antiepileptik ilaçların, üreme endokrin fonksiyonları üzerindeki etkilerinin 
çoğu hayvan modellerinde araştırılarak doğrulanmıştır ${ }^{2,6}$.

Ayrıca, VPA 'nın ovaryumda ergenlik öncesinden yetişkinliğe kadar apoptotik etkilere ve folikülogenez bozukluğuna yol açtığı bilinmektedir ${ }^{7}$. Daha önceki bir çalışmamız, VPA 'nın uterusta apoptotik ve dejeneratif etkilerine ek olarak eozinofil infiltrasyonuna yol açtığını ortaya koymuştur. İmplantasyon, dişi üreme fizyolojisindeki anahtar olaydır. Başarılı implantasyon, uterustaki desidual yapının gelişmesine ve trofoblast hücreleri ile doğru iletişime bağlıdır. Normal implantasyonda, birincil trofoblast hücreleri istilayı başlatır ve desidual hücrelerin farklanması için uterustaki fibroblast hücrelerini tetikler9,10.

Prostaglandinler (PG 'ler), embriyo implantasyonu için uzun süredir gerekli olduğu bilinen bir grup biyoetkin lipid bileșiğidir. Fosfolipaz A2 ve siklooksijenaz-2 (COX-2) dahil olmak üzere $P G$ 'lerin sentezi için enzimlerin bozukluk ya da yokluğu, farelerde implantasyon başarısızlığına neden olur ${ }^{11}$. İnsanlarda, gebelik sırasında PG sentezini baskılayan nonsteroid antiinflamatuvar ilaçlara etkin kalma, düşük yapma riskini önemli ölçüde artırmaktadır ${ }^{12}$. Sitotrofoblast hücreleri tarafından ifade edilen çeşitli temas faktörleri ve çözünür faktörler, plasenta gelişimi sırasında hormon, sitokin, anjiyogenik ve büyüme faktörü sentezi üzerindeki bölgesel etkilere aracılık eder ${ }^{13}$. Vazoaktif intestinal peptid (VIP), bir peptid hormondur ve reseptörleri olan VIPC1 ve VIPC2 'ye bağlanarak damar genişletici, salgılayıcı ve immünomodülatör etki gösterir ${ }^{14}$. VIP, gebeliğin olaylandığı ilk günlerden itibaren birinci trimester süresince trofoblast hücreleri tarafindan ifade edilir ${ }^{15}$. Literatürde, antiepileptik bir ajan olan VPA 'nın implantasyon bölgesinde proliferatif belirteçler olan vazoaktif intestinal peptit (VIP) ve siklooksijenaz-2 (COX-2) üzerinden değerlendirildiği herhangi bir çalışma bulunmamaktadır. Çalışmamızın amacı; VPA uygulanan diși sıçanlarda embriyo implantasyonunda COX-2 ve VIP moleküllerinin implantasyon döneminde dağılımının araștırılmasıdır.

\section{YÖNTEMLER}

\section{Deney Hayvanları ve Gruplandırma}

Deney hayvanları, Atatürk Üniversitesi Tıbbi Deneysel Uygulama ve Araştırma Merkezinden temin edilmiştir. Deneyde kullanılan Wistar albino cinsi 20 adet dişi sıçan 150-200 gram ağırlığında genç erişkin sıçanlardı ve çalışma süresince 22-25 ${ }^{\circ} \mathrm{C}$ oda isısinda, 12 saat aydınlık/12 saat karanlık döngüleri içeren ortamda, standart gıda ve suya serbest erişimli olarak tutuldular. İki gruba randomize olarak bölünen dişi sıçanlardan, 1. Grup Kontrol, 2. Grup VPA Grubu olarak belirlendi. 1. Gruba; 90 gün boyunca salin solusyonu intraperitoneal olarak iki doz șeklinde uyguland. 2. Gruba ise 90 gün boyunca $300 \mathrm{mg} / \mathrm{kg} /$ gün $\mathrm{VPA}$ intraperitoneal olarak iki doz şeklinde uyguland. Vajinal smear ile siklus kontrolleri yapılan dişiler, bir gece erkek sıçanlarla aynı kafeste tutularak çiftleştirildiler. Vajinal plak kontrolü yapılarak, çiftleşme günü 0. Gün kabul edildi ve 7. Günde denekler yüksek doz anestezi altında feda edilerek uterus implantasyon bölgesi dokuları çıkartıldı. Deney için; 75296309-050.01.04-E.2000239275 kod numarası ile Atatürk Üniversitesi Hayvan Deneyleri Yerel Etik Kurul Başkanlığı'ndan Etik Kurul onayı alınmıştır.

\section{Işık Mikroskobik Yöntem}

Deneklere ait dokular $10 \%$ formaldehit solüsyonu içerisine alınarak 72 saat tespit edildi. Tespit işlemi sonrasında, dokular kasete alınarak 24 saat akar suda yıkandı ardından artan alkol serilerinden $(\% 70, \% 80, \% 90$, ve $\% 100)$ geçirilerek sudan arındırıldı. Ksilolde şeffaflaştırılan testis dokuları parafin bloklara gömülerek 4-5 mikron kalınlığında kesitler alındı. Alınan kesitler hematoksilen - eozin ikili boyaması ile boyanarak Olympus DP2-SAL 
firmware program'da (Olympus® Inc. Tokyo, Japan) değerlendirildi ve fotoğraflandı.

\section{İmmünohistokimyasal Yöntem}

İmmünohistokimya için alınan kesitler, kesitler Tris tamponunda (Sigma-Aldrich, St. Louis, ABD) $\% 2$ tripsin ile $37 \circ \mathrm{C}$ 'de 15 dakika bekletildi ardından, 15 dakika süreyle metanolde çözdürülmüş $\% 0,3$ 'lük $\mathrm{H} 2 \mathrm{O} 2$ blok solüsyonuna (Invitrogen, CA, ABD) etkin bırakıld. Daha sonra kesitler; 1:100 oranında hazırlanmış olan COX-2 (Fare monoklonal) ve VIP (Fare monoklonal) primer antikorları ile nemli ortamda ve $4{ }^{\circ} \mathrm{C}$ 'de 1 saat inkübe edildi. Kesitler inkübasyon sonrasında kit içerisindeki üretici talimatları izlenerek biyotinlenmiş sekonder antikorla ve ardından streptavidin konjuge horseradish peroksidazla (Invitrogen, CA, USA) 30 'ar dakika inkübe edildi. Son olarak kesitler, 3-amino-9-ethylcarbazole (AEC, Spring, CA, USA) ile 3-5 dakika süreyle inkübe edilerek, Mayer's hematoksilenle boyanarak Olympus DP2-SAL firmware program'da (Olympus® Inc. Tokyo, Japan) değerlendirildi ve fotoğraflandı. Boyamalarda her bir preparatta X400 büyültmede rasgele beş alan seçilerek dokularda boyanan pozitif hücre tutulumların yoğunluğuna ve tutulum miktar yüzdesine göre $\mathrm{H}$ skoru hesaplandı. Tutulum yoğunluğu semi kantitatif olarak $0(0$, tutulum yok), 1 (+, zayıf immünreaktivite), $2(++$, orta düzeyde immünreaktivite), $3(+++$, kuvvetli düzeyde immünreaktivite) olarak skorlandırıldı. Tutulum miktar yüzdesi immünreaktivitenin

hücre/yapıların toplam hücre/yapılara oranlanması ile; 1 (\%0-10 arası, fokal), 2 (\%1150 arası, bölgesel) ve 3 (\%51-100 arası, diffüz) olarak skorlandırıldı. Her bir alan için bulunan yoğunluk ve miktar skorları $\Sigma$ Pi.(i+1) $(\mathrm{Pi}=$ tutulum miktar yüzdesi, i= tutulum yoğunluğu) formülü ile hesaplanarak, sonuçlar toplanarak o lam için tek bir değere ulaşıldı. Histopatolojik değerlendirme çalışma grupları için çift kör bir histolog tarafından gerçekleștirildi.

\section{İstatistiksel Yöntem}

Verilerin istatistiksel analizinde IBM SPSS 22 (Armonk, NY: IBM Corp.) paket programı kullanıldı. Sürekli değişkenlere ait tanımlayıcı istatistikler ortalama \pm standart sapma, medyan (minimum-maksimum) değer, kategorik değişkenler ise sayı (\%) olarak sunuldu. COX-2 ve VIP antikorlarına ait değişkenlerinin normal dağılıma uygunluğu Shapiro-Wilks testi ile kontrol edildi. Normal dağılım varsayımı sağlandığından gruplar arasındaki karşılaştırmalar bağımsız örneklemlerde $t$ testi ile yapıldı. Tüm istatistiksel testlerde, $\mathrm{p}<0.05$ olan durumlar istatistiksel olarak anlamlı kabul edildi.

\section{BULGULAR}

Çalışmamızda yapmış olduğumuz histolojik değerlendirmelerde, hematoksilen - eozin ikili boyamasında 7. Gün uterus dokularında gebeliğin olaylandığını gözlemledi. Uterus duvar kalınlığının fazla olduğu, lümenin oldukça dar bir görünüm sergilediği ve implantasyon bölgesinde geniş bir endometriyal alanı kapsayan desidual farklanmanın gerçekleștiği dikkati çekti. İmplantasyon bölgesinde trofoektoderm hücrelerinin varlığı ve yine desidual dokunun oluştuğu uterus endometriyumunda yer yer dar lümenleriyle uterus bezlerinin varlığı ilgiyi çekti (Fotoğraf 1 ).

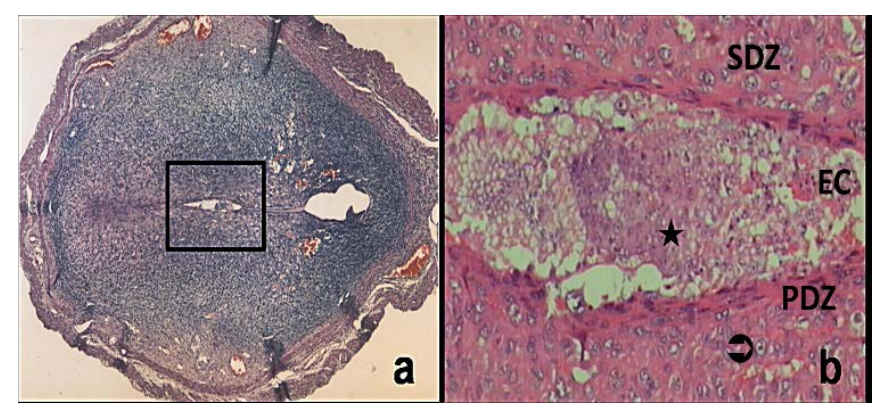

Fotoğraf 1: Hematoksilen-eozin ile boyanmış uterus dokusu implantasyon bölgesi kesitinde; (a X40) küçük büyültme $\square$ : implantasyon bölgesi ve (b X100) büyük büyültmede, $\star$ : embriyo trofoektoderm hücreleri, EC: ektoplasental hücreler, PDZ: primer desidual zon, SDZ: sekonder desidual zon, $\boldsymbol{\vartheta}$ : desidua hücresi ile bölgede implantasyonun olaylandığı dikkati çekiyor. 
COX-2 primer antikoru ile yapılan immünohistokimyasal işaretlemede 7. Gün kontrol grubuna ait kesitlerde, desidua katmaninda (a), embriyonun trofoektoderm hücrelerinde (b) ve uterus bez epitelinde (c), çekirdek düzeyinde ve kuvvetli bir immünreaksiyon izlendi. 7. Gün VPA grubuna ait kesitlerin COX-2 antikoru ile yapilan işaretlemesinde ise, immünreaksiyonun desidua katmanında (d), embriyonun trofoektoderm hücrelerinde (e) ve uterus bez epitelinde (f) yine çekirdek düzeyinde ve zayıf olduğu ilgiyi çekti (Fotoğraf 2).

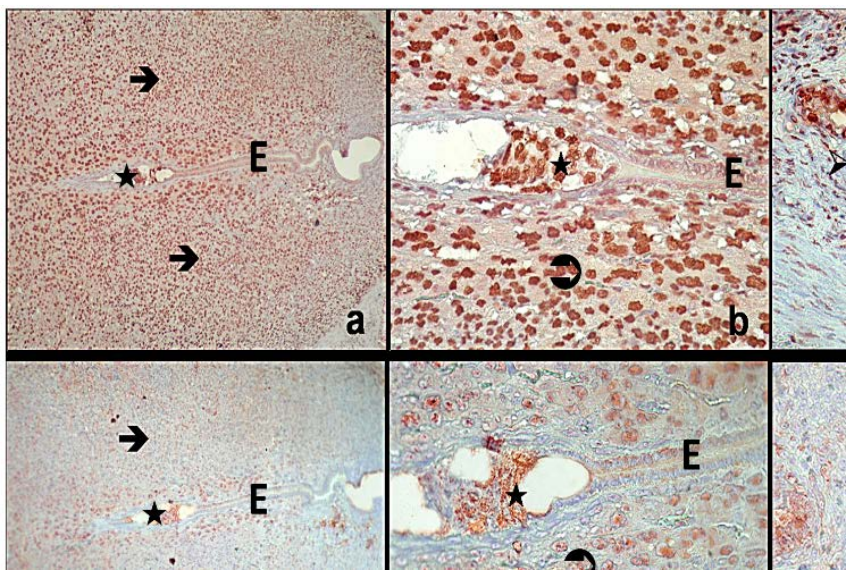

Fotoğraf 2: COX-2 primer antikoru ile yapılan işaretlemede uterus dokusuna ait kontrol grubu kesitlerinde, (a) uterus desidua katmanında, (b) embriyo trofoektoderm hücrelerinde ve (c) uterus bez epitelinde kuvvetli tutulum izleniyor. VPA grubuna ait kesitlerde ise , (d) uterus desidua katmanında, (e) embriyo trofoektoderm hücrelerinde ve (f) uterus bez epitelinde zayıf tutulum gözlemleniyor; $\rightarrow$ : uterus desidua katmanı, E: luminal epitelyal hücreler, $\star$ : embriyo trofoektoderm hücreleri, $\boldsymbol{\vartheta}$ : desidua hücresi, $>$ : uterus bezi, (X400).

VIP primer antikoru ile yapılan immünohistokimyasal işaretlemede 7. Gün kontrol grubuna ait kesitlerde, desidua katmanında (a) zayıftan ortaya değişen kuvvette immünreaksiyon gözlemlenirken, embriyonun trofoektoderm hücrelerinde (b) orta kuvvette, uterus bez epitelinde (c) ise zayıf - orta kuvvette immünreaksiyon ayırt edildi. 7.
Gün VPA grubuna ait kesitlerin VIP antikoru ile yapılan işaretlemesinde ise, desidua katmanında (d), embriyonun trofoektoderm hücrelerinde (e) ve uterus bez epitelinde (f) negatiften zayıfa değișen immünreaksiyon gözlemlendi (Fotoğraf 3).

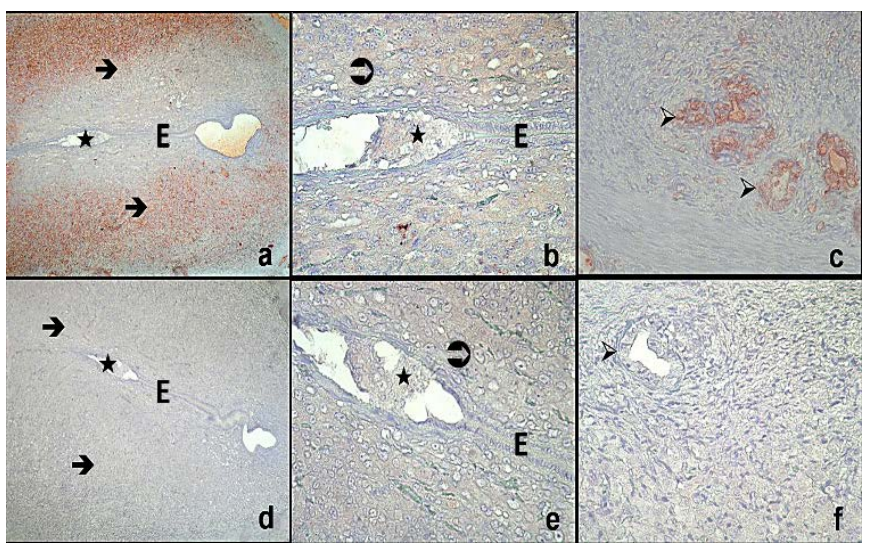

Fotoğraf 3: VIP primer antikoru ile yapılan işaretlemede uterus dokusuna ait kontrol grubu kesitlerinde, (a) uterus desidua katmanında, (b) embriyo trofoektoderm hücrelerinde ve (c) uterus bez epitelinde zayıfdan orta şiddete değișen tutulum izleniyor. VPA grubuna ait kesitlerde ise , (d) uterus desidua katmanında, (e) embriyo trofoektoderm hücrelerinde ve (f) uterus bez epitelinde negatif - zayif tutulum gözlemleniyor; $\rightarrow$ : uterus desidua katmanı, E: luminal epitelyal hücreler, $\star$ : embriyo trofoektoderm hücreleri, ๑: desidua hücresi, $>$ : uterus bezi, (X400).

Çalışma gruplarının immünohistokimyasal boyamaları sonucunda; tutulum gösteren hücreler sayılmış ve gruplar arasındaki farklar istatistiksel olarak araştırılmıştır. Verilerin analiz sonuçları Tablo I 'de sunulmuştur. Çalışma gruplarında COX-2 tutulumu gösteren hücrelerin gruplar arasındaki sayıları incelendiğinde VPA grubunda düzeyin (51.0 \pm 4.4$)$, kontrol grubuna göre $(123.2 \pm 6.3)$ daha düşük olduğu bulunmuştur $(\mathrm{p}<0.001)$. Benzer şekilde VIP antikoru ile tutulum gösteren hücrelerin düzeyi de VPA grubunda (43.0 \pm 2.9$)$, kontrol grubuna $(75.7 \pm 10.4)$ göre daha düşük olarak tespit edilmiştir $(\mathrm{p}<0.001)$. 
Tablo I: Çalışma grupları arasında, COX-2 ve VIP antikorlarının tutulum düzeyleri arasındaki istatistiksel karşılaştırma

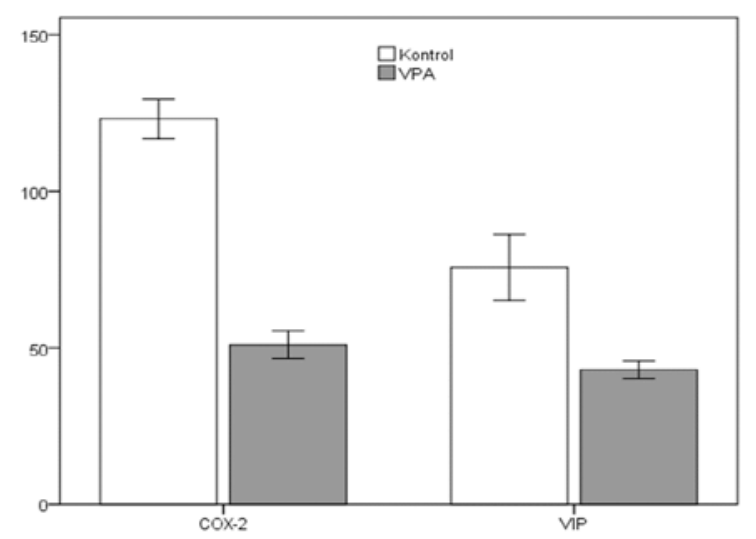

TARTIŞMA

Güncel çalışmamızda, uzun süreli VPA uygulamasının, gebeliği olaylanmış dişi sıçanlarda implantasyon bölgesindeki COX-2 ve VIP ifadelenmesine olan etkisini araștırmayı amaçladık.

Epilepsi, kavramsal olarak 2005 yılında epileptik nöbetler oluşturmaya yönelik kalıcı yatkınlıkla karakterize bir beyin hastalığı olarak tanımlanmıştır. Halk arasında "Sara hastalığı" olarak da bilinen epilepsi, kısa süreli beyin fonksiyon bozukluğuna bağlı olarak gelișen ve sinir hücrelerinin olağan dişı bir elektrokimyasal boşalım yapması sonucu ortaya çıkan nörolojik bir hastalıktır. Epilepsinin, antiepileptik ilaçlar ve üreme sistemi ile karmaşık bir etkileşimi olduğu bilinmektedir ${ }^{16}$. Epilepsi hastaları arasında üreme endokrin hastalıkları normal populasyona göre daha sıktır. Epilepsinin kendisi bu hastalıklara yol açarken, antiepileptik ilaçlar da önemli bir ajandır ${ }^{16}$. VPA, epilepsi ve bipolar bozukluklar, migren ve genelleştirilmiş duygu durum bozuklukları gibi diğer nöropsikiyatrik hastalıkların tedavisinde yaklaşık 50 yıldır yaygın olarak kullanılmaktadır9,17. VPA ile uzun süreli tedavinin polikistik over sendromu, hiperandrojenizm, hiperprolaktinemi, hiperinsülinemi ile ilişkili olduğu bilinmektedir. Luteinize edici hormon, folikül uyarıcı hormon ve tiroid hormonlarındaki değişiklikler; epilepsi hastası kadınlarda ovaryum yetmezliği, adet anormallikleri ve amenore ile kendini gösteren birçok üreme bozukluğuna neden olmaktadır ${ }^{18}$. Epilepsinin kendisi nöroendokrin anormalliklerle ilişkilendirilse de, bu anormalliklerden antiepileptiklerin özellikle VPA 'nın da sorumlu olduğu birçok araştırma ile ortaya konulmuştur? ${ }^{7}$ VPA 'nın üreme ve nöroendokrin sistem üzerindeki etkisine ilişkin çalışmalar çoğunlukla yetişkin hastalara odaklanmaktadır ancak VPA 'nın hem epilepsi hastası çocuklar hem de yetişkinler için yaygın olarak kullanıldığı gerçeği göz ardı edilmemelidir? ${ }^{7}$.

VPA 'nın ovaryum folliküllerinde steroidogeneze olan etkisini araştıran bir çalışmada, domuz ovaryumlarından toplanan östrus fazındaki folliküllerden, teka interna ve granulosa hücreleri izole edilerek kültüre edilmiş ve farklı dozlarda VPA 'ya etkin bırakılmıştır. VPA uygulamasının doza bağlı artan bir şiddette, hem östradiol ve testosteron salgısını hem de progesteron salgılanmasını baskılayarak azalttığı gözlemlenmiştir. Sözü edilen çalışmada bunların yanı sıra testosteronun östradiole dönüşümünün de engellendiği sonucuna varılmış ve böylelikle VPA 'nın steroidogenez üzerine doğrudan etkisi olduğu kanıtlanmıștır ${ }^{19}$. Yine VPA uygulamasının, epileptik olmayan sağlıklı sıçanlarda da ovaryumlarda kist oluşumunu tetiklediği ve steroid hormon düzeylerini etkilediği yapılan çalışmalarda belirtilmiştir ${ }^{19}$. Maya kültürleri kullanılarak yapılan bir moleküler çalışmada, VPA 'ya etkin bırakılan maya kültürlerinde VPA 'nın androjen ve progesteron reseptörleri için steroidal olmayan bir antagonist olarak çalıştığı ortaya konulmuştur, bu şekildeki antagonist etkinin ise 
endokrin üreme bozukluğunun primer sebeplerinden olabileceği düşünülmüştür ${ }^{20}$. Daha önce yapmıș olduğumuz çalıșmalarımızda, yeni epilepsi teşhisi almış ve tiroid fonksiyonları normal olan çocukların kısa süreli VPA kullanımının ardından tiroid hormon seviyelerinin değiștirdiği ve klinik olarak VPA ile tedavi edilen epileptik çocuklarda tiroid fonksiyonlarının da sürekli takibinin gerekli olduğu sonucuna ulaşılmıştır21.

VPA kullanımın ergenlik öncesi dönemden yetişkinliğe kadar olan dönemde ovaryumda follikülogenezi bozarak, folliküler hücrelerde apopitozise neden olduğu ${ }^{7}$, uterus dokusunda elektron mikroskobik düzeyde yapılmış araştırmada ise VPA 'ya etkin kalmanın uterus stromasinda apopitozu, mitokondriyal hasarı ve hücresel ödemi olaylandırdığı tespit edilmiștir8. 2020 yılında yapılmış olan bir derlemede ise literatür birikimi doğrultusunda, üreme çağındaki epilepsi hastası kadınlarda, yüksek teratojenik etkisi ve kongenital malformasyon riski sebebiyle VPA 'nın başka ilaçlarla değiștirilmesi gerektiği salık verilmektedir ${ }^{22}$.

$\mathrm{Ne}$ yazlk ki günümüz verileri değerlendirildiğinde gebeliklerin yaklaşık $\% 50$ 'sinin plansız gerçekleşmesi sebebiyle, uygulanan medikal tedavilerin sebep olduğu etkilerden kaçınmak oldukça güçtür. $\mathrm{Bu}$ sebeple, VPA gibi üremeye olumsuz etkileri bilinen ilaçların; gebeliğin erken dönemi ve ilk trimesterdeki etkilerini daha yakından araştırmak gereklidir. Gebelik, embriyo implantasyonu, gelişimi ve yerleştirilmesi gibi karmaşık süreçleri içerir. Trofoblastın uterus endometriyumuna yapıșması ve invazyonu bu süreçteki en kritik olaylardan biridir ve hücre dışı matris proliferasyonu, farklanma, yapışma, yer değiştirme, yıkım ve yenilenme gibi bir dizi hücresel davranışı içerir 23. Bu kontrol mekanizmasındaki herhangi bir hata, eksik implantasyon, preeklampsi ya da abortus gibi ciddi komplikasyonlara yol açacaktır ${ }^{9}$. Birçok yazar memelilerde implantasyon sirasinda endometriyumda morfolojik değişiklikler göstermiştir. Yapılan çalışmalarda, desidualizasyonun ilk olarak siçanlarda gebeliğin 6. gününde göründügünü bildirmiştir ${ }^{24}$. Diğer bir çalışmada ise; implantasyon bölgesini çevreleyen subepitelyal hücrelerin olgun desidual hücrelere dönüştüğünü göstermiştir ${ }^{25}$.

PG 'ler, embriyo implantasyonu için uzun süredir gerekli olduğu bilinen bir grup biyoetkin lipid bileșiğidir. Fosfolipaz A2 ve COX2 de dahil olmak üzere PG 'lerin sentezi için enzimlerin bozukluk ya da yokluğu, farelerde implantasyon başarısızlığına neden olmaktadır ${ }^{11}$. PTGS2 geni tarafindan kodlanan COX-2, aynı zamanda prostoglandin endoperoksit sentaz-2 olarak bilinen bir enzimdir. COX-2 artışı ise kanserli dokularda defektif apoptozisten, immün baskılamadan, tümör hücre proliferasyonu, anjiyogenez ve metastaz potansiyeli artışından sorumludur. COX-2 'nin üreme sürecindeki çok sayıda aşamada özellikle embriyo implantasyonunda önemli rol oynadığı bilinmektedir. COX2 ayrıca vasküler geçirgenlikte ve anjiyogenezde kritik bir rol oynar. Eksikliği, düşük anjiyogenez ile karakterize edilen implantasyon başarısızlığına yol açar ${ }^{26}$. PG 'ler; araşidonik asitten üretilen kimyasallardır ve COX2, prostaglandinlerin sentezine aracllık eden anahtar bir enzimdir. Son yllarda, endometriyal hasar ve gebelik sırasında mikrosirkülasyonu ve trofoblast invazyonunu iyileștirebilecek aspirin, heparin ve sildenafil gibi ilaçların kullanımı da dahil olmak üzere endometriyal alıcılığı artırmaya odaklanma girişimleri yapılmıștır ${ }^{27,28}$.

COX, iki ayrı gen, COX-1 ve COX-2 tarafından kodlanan iki izoformda bulunur. Farelerde gen susturma deneyleri, bu izoformlar için farklı işlevler oluşturmuştur. COX-1 eksikliği olan dişiler özgün doğum kusurlarıyla doğurgan olmalarına rağmen, COX-2 eksikliği olan dișiler ovulasyon, döllenme, implantasyon ve desidualizasyonda anormalliklerle seyreder 
şekilde büyük ölçüde infertildir ${ }^{29}$. Sıralanan özelikleri sebebiyle COX-2 başarılı implantasyonun göstergesi olarak kullanılabilecek bir işaretleyicidir. Çalışmamızda, implantasyonun 7. Gününde kontrol grubunda yaptığımız immünohistokimyasal değerlendirmede COX-2 'nin, desidua hücrelerinde, embriyonun trofoektoderm hücrelerinde ve uterus bez epitelinde kuvvetli poztifilik gösterdiğini belirledik. Fakat, VPA uygulanmış gruba ait kesitlerde COX-2 immünreaksiyonunun şiddetinin desidua hücrelerinde, embriyonun trofoektoderm hücrelerinde ve uterus bez epitelinde azalmış olduğu dikkati çekti.

VIP; vazodilatasyonu ve düz kas aktivitesini düzenleyip, epitelial hücre sekresyonunda ve gastrointestinal bölgede kan akımının düzenlenmesinde rol oynamaktadır. İntestinal fizyolojide oldukça önemli olan bir nöromodülatör ve nörotransmitterdir. Ayrıca trofoblastlar tarafından üretilir ve maternal immün cevabı yönetir ${ }^{13}$.

Sitotrofoblast hücreleri tarafindan ifade edilen çeşitli temas faktörleri ve çözünür faktörler, plasenta gelişimi sırasında hormon, sitokin, anjiyogenik faktörler ve büyüme faktörü sentezi üzerindeki bölgesel etkilere aracılık eder ${ }^{13}$. VIP, bir peptid hormondur ve reseptörleri olan VIPC1 ve VIPC2 'ye bağlanarak damar genişletici, salgılayıcı ve immünomodülatör etki gösterir14. VIP, gebeliğin olaylandığı ilk günlerden itibaren birinci trimester süresince trofoblast hücreleri tarafından ifade edilir ${ }^{15}$. Anjiyogenezi doğrudan ve dolaylı olarak etkilediği bilinen VIP 'nin trofoblast hücrelerindeki eksikliği adezyonda önemli olan matriks metalloproteazlarının (MMP) ifadelenmesini de önemli ölçüde azaltmaktadır ${ }^{13}$. Bunun dıșında, VIP 'nin infertil bireylerde uterus alıcılığını ve embriyo implantasyon başarısını arttırıcı bir tedavi faktörü olarak da kullanıldığı çalışmalar mevcuttur ${ }^{30}$. Biz de çalışmamızda üreme bozukluğuna birçok yönden sebep olduğu bilinen VPA 'nın implantasyonun7. Günündeki sıçan uterusunda ifadelenmesinin olası değişimini araştırdığımızda, kontrol grubu ile karşılaştırıldığında 7. Gün VPA grubunda, VIP immünreaksiyonunun desidua hücrelerinde, embriyonun trofoektoderm hücrelerinde ve uterus bez epitelinde çoğunlukla negatif olduğunu gözlemledik.

Sonuç olarak, çalışmamızda VPA 'nın uzun süre kullanımının gebelik sürecinde COX-2 ve VIP 'nin ifadelenmesini azalttığı; bu azalmanın da embriyo implantasyonunu ve dolayısiyla gebeliğin ilerlemesini olumsuz yönde etkileyerek risk oluşturabileceği kanısına varılmıștır.

Etik Kurul Kararı: Deney için; 75296309050.01.04-E.2000239275 kod numarası ile Atatürk Üniversitesi Hayvan Deneyleri Yerel Etik Kurul Başkanlığı'ndan Etik Kurul onayı alınmıştır.

Çıkar Çatışması Beyanı: Yazarlar çıkar çatışması olmadığını bildirmişlerdir.

Finansal Destek: Bu çalışma herhangi bir fon tarafından desteklenmemiştir.

Declaration of Conflicting Interests: The authors declare that they have no conflict of interest.

Financial Disclosure: No financial support was received.

\section{KAYNAKLAR}

1. Iliescu C, Tarta-Arsene O, Craiu D. Valproic acid, polycystic ovary syndrome and the adolescent with epilepsy. Farmacia. 2017; 65: 1-4.

2. Death, AK, Kristine CY, McGrath DJ, et al. Valproate is an anti-androgen and anti-progestin. Steroids. 2005; 70: 946-53.

3. Morrell MJ. Reproductive and metabolic disorders in women with epilepsy. Epilepsia. 2003; 44: 11-20.

4. Bilo L, Meo R, Nappi C. Reproductive endocrine disorders in women with primary generalized epilepsy. Epilepsia. 1988; 29: 612-9. 
5. Rattya J, Turkka J, Pakarinen AJ, et al. Reproductive effects of valproate, carbamazepine, and oxcarbazepine in men with epilepsy. Neurology. 2001; 56: 31-6.

6. Sveberg RL, Tauboll E, Berner A, et al. Morphological changes in the testis after longterm valproate treatment in male Wistar rats. Seizure. 2001; 10: 559- 65.

7. Cansu A, Giray SG, Serdaroglu A, et al. Effects of chronic treatment with valproate and oxcarbazepine on ovarian folliculogenesis in rats. Epilepsia. 2008; 49: 1192-1201.

8. Cansu A, Erdogan D, Serdaroglu A, et al. Histologic and morphologic effects of valproic acid and oxcarbazepine on rat uterine and ovarian cells. Epilepsia. 2010; 51: 98107.

9. Gurgen SG, Erdogan D, Coskun ZK, et al. The effect of valproic acid and oxcarbazepine on the distribution of adhesion molecules in embryo implantation. Toxicology. 2012; 292: 71-7.

10. Parr MB, Parr EL. The implantation reaction, Biology of the Uterus. Plenum. 1989; 233-77.

11. Lim H, Paria BC, Das SK, et al. Multiple female reproductive failures in cyclooxygenase 2-deficient mice. Cell. 1997; 91: 197-208.

12. Chen JJ, Wang Y, Meng X, et al. MRP4 regulates ENaCdependent CREB/COX-2/PGE2 signaling during embryo implantation. Oncotarget. 2017; 8: 78520.

13. Paparini DE, Choudhury RH, Vota DM, et al. Vasoactive intestinal peptide shapes first-trimester placenta trophoblast, vascular, and immune cell cooperation. $\mathrm{Br} \mathrm{J}$ Pharmacol. 2019; 176: 964-80.

14. Ganea D, Hooper KM, Kong W. The neuropeptide vasoactive intestinal peptide: Direct effects on immune cells and involvement in inflammatory and autoimmune diseases. Acta Physiol. 2015; 213: 442-52.

15. Marzioni D, Fiore G, Giordano A, et al. Placental expression of substance $P$ and vasoactive intestinal peptide: evidence for a local effect on hormone release. J Clin Endocrinol Metab. 2005; 90: 2378-83.

16. Bilo L, Meo R, Nappi C, et al. Reproductive endocrine disorders in women with primary generalized epilepsy. Epilepsia. 1988; 29: 612-9.

17. Peterson GM, Naunton M. Valproate: a simple chemical with so much to offer. J Clin Pharm Ther. 2005; 30: 417-21.

18. Isojarvi JIT, Tauboll E, Herzog AG. Effect of antiepileptic drugs on reproductive endocrine function in individuals with epilepsy. CNS Drugs. 2005; 19: 207-23.
19. Gregoraszczuk E, Wójtowicz AK, Tauboll E, et al. Valproate-induced alterations in testosterone, estradiol and progesterone secretion from porcine follicular cells isolated from small-and medium-sized ovarian follicles. Seizure. 2000; 9: 480-85.

20. Death AK, McGrath KC, Handelsman DJ. Valproate is an anti-androgen and anti-progestin. Steroids. 2005; 70: 946-53.

21. Cansu A, Serdaroglu A, Camurdan 0, et al. The evaluation of thyroid functions, thyroid antibodies, and thyroid volumes in children with epilepsy during shortterm administration of oxcarbazepine and valproate. Epilepsia. 2006; 47: 1855-59.

22. Kuo CY, Liu YH, Chou IJ, et al. Shifting valproic acid to Levetiracetam in women of childbearing age with epilepsy: a retrospective investigation and review of the literature. Front Neurol. 2020; 11: 330.

23. Chakraborty C, Gleeson LM, McKinnon T, et al. Regulation of human trophoblast migration and invasiveness. Can J Physiol Pharmacol. 2002; 80: 116-24.

24. Welsh AO, Enders AC. Occlusion and reformation of the rat uterine lumen during pregnancy. Am J Anat. 1983; 167: 463-77.

25. Abrahamsohn PA, Zorn TMT. Implantation and decidualization in rodents. J Exp Zool. 1993; 266: 603-28.

26. Song Y, Zhou F, Tan X, et al. Bushen Huoxue recipe attenuates early pregnancy loss via activating endometrial COX2-PGE2 angiogenic signaling in mice. BMC Complem Altern M. 2021; 21: 1-15.

27. Yu X, Gao C, Dai C, et al. Endometrial injury increases expression of hypoxia-inducible factor and angiogenesis in the endometrium of women with recurrent implantation failure. Reprod BioMed Online. 2019; 38: 761-7.

28. Groom KM, David AL. The role of aspirin, heparin, and other interventions in the prevention and treatment of fetal growth restriction. Am J Obstet Gynecol. 2018; 218: 829-40.

29. Matsumoto H, Ma WG, Daikoku $T$, et al. Cyclooxygenase-2 differentially directs uterine angiogenesis during implantation in mice. J Biol Chem. 2002; 277: 29260-67.

30. Gallino L, Hauk V, Fernández L, et al. VIP Promotes Recruitment of Tregs to the Uterine-Placental Interface During the Peri-Implantation Period to Sustain a Tolerogenic Microenvironment. Front Immunol. 2020; 10: 2907. 